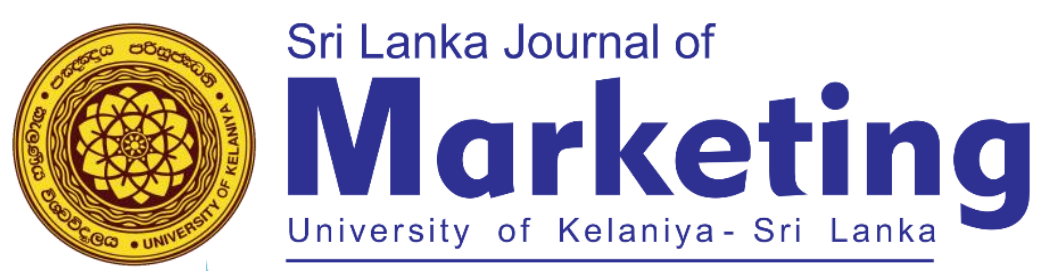

\title{
Determinants of Financial Literacy: with Special Reference to Consumers in Financial Service Industry
}

\author{
Kumari D.A.T \\ Senior Lecturer, Wayamba University of Sri Lanka \\ datkumari@wyb.ac.lk
}

\section{ABSTRACT}

The financial literacy is a key dimension which determines the demand of the financial services in the economy. However, most of the previous studies and financial decision makers believe financial literacy in different perspectives. Therefore, it is timely important to identify the main determinants of the financial literacy among potential customers in financial service industry. Accordingly, present study is mainly focused on identifying and verifying the key determinants of the financial literacy in the customer's point of view in the financial service sector. The study adopted the positivism epistemology and quantitative approach. At the initial phase of the study, the extensive literature review was carried out with the purpose of identifying the determinants of financial literacy. In the second phase, a survey was conducted among 500 potential financial services customers representing nine provinces in Sri Lanka, with the assistance of a researcher administrated questionnaire. The sample was selected based on the multilevel mixed sampling method and the unit of analysis was the head of households in Sri Lanka. Furthermore, a partial least squares structural equation model (PLS-SEM) was employed as the principle data analysis approach, and Smart PLS 3 was employed as the main analytical software. Degree of financial literacy was tested based on 22 items identified by previous researchers and Principle Component Analysis was employed to determine the key factors of financial literacy. The reliability of scales was measured by Cronbach's Alpha coefficients.

The findings revealed that in general, all financial literacy dimensions have significant impact to determine the level of financial literacy. However, when it considers under separate dimensions, financial knowledge is the most significant determinant among the other determinants to determine the level of financial literacy. Therefore, researcher concluded that financial knowledge can be considered as a main determinant of financial literacy among potential customers of financial services in Sri Lanka. And the financial awareness is identified as the least significant determinant. Finally, the researcher provides some suggestions for marketing practitioners of financial service industry and government policy decision makers to develop financial literacy level by promoting financial knowledge for absorbing more consumers towards formal financial system and products of financial services.

Keywords: Financial Awareness, Financial Attitude, Financial Behavior, Financial Knowledge, Financial Literacy, Financial Skills 


\section{INTRODUCTION:}

Although financial literacy is frequently discussed in the national arena there is no clear definition of financial literacy; this ambiguity has led to multiple definitions. Financial literacy was defined by Mason and Wilson (2000) as "an individual's ability to obtain, understand, and evaluate the relevant information necessary to make decisions with an awareness of the likely financial consequences". According to Noctor, Stoney and Stradling (1992), financial literacy is the ability to make informed judgments and to take effective decisions regarding the use and management of money. This definition was adopted by several scholars for their studies (E.g. Adam et al., 2018; Beal \& Delpachitra 2003; Bhargava, 2017; McKenzie 2009; Rai et al.,2019; Sandra, 2010; Xiao \& Porto, 2017;). Further Shawn and Cole (2008), emphasis that financial literacy is the ability to process financial information and make informed decisions about personal finance and it has received growing attention in the developed world and, recently, in the developing world, as a potentially important determinant of household well-being. It also means learning about finance and money which will help one to take better financial decisions in the life (Sheetal, 2013). According to aforesaid definitions, financial literacy means knowledge about finance. In layman's language it means providing financial knowledge to those people who are not aware of financial products and services (Sheetal, 2013). Accordingly, financial literacy can be simply defined as peoples' ability to process economic information and make informed decisions about financial planning, wealth accumulation, debt, and pensions (Lusardi, 2014).

Financial literacy facilitates the growth and the moulding of finances in an apt manner. As it influences not just the welfare of people, but also their financial empowerment, the significance of financial literacy is not to be underestimated. As the conversion of economy from general literacy to financial literacy is fundamental to old and young, men and women, domestic and working populations, financial literacy accommodates them all. Well informed financial decision making is turning into a requirement for financial wellbeing of an individuals, as a result of constant shifting in the financial market and the intensification of individual responsibility. During the last few years, the financial literacy has been a popular area which was investigated most energetically around the world, as financial knowledge was considered to be the key element for making sturdy financial decisions (Al-Tamimi \& Hussain, 2009; Arrondel et al., 2013; Lusardi \& Mitchell,2014; Lusardi \& Alessie, 2011; Maheswari et al., 2016; Kumari, 2020a).

Financial literacy and proper financial inclusion are two indispensable factors for the financial welfare and financial empowerment of people (Kumari, 2017). For a better maintenance and wellbeing, financial planning and independent decision making on income and its effective management is a key factor. As citizens of a developing country, Sri Lankan people have to confront many challenges so as to obtain financial knowledge. Further she explained that, the majority of people are poor in financial literacy and particularly, lack of knowledge and proper financial attitudes and therefore, poor in 
financial decision making.

In comparison to a number of other Asian countries, Sri Lanka has a financial inclusion rate as high as 73.6\%, as stated by the Little Data Book on Financial Inclusion, 2018. All adults (above 15 years) who possess an account in formal financial sector were considered as "Financially Inclusive" table 1. demonstrates that the Sri Lankan population is deprived of any form of financial services (S\&P Global Fin Lit Survey, 2018). This exclusion of the formal financial market is the outcome of financial illiteracy and lack of a sound financial attitude.

Table 1: Financial Inclusion and Financial Literacy in Asian Countries

\begin{tabular}{|l|c|c|}
\hline \multicolumn{1}{|c|}{ Country } & $\begin{array}{c}\text { Financial } \\
\text { Inclusion*(\%) }\end{array}$ & $\begin{array}{c}\text { Adults who are Financially } \\
\text { Literate (\%) }\end{array}$ \\
\hline Malaysia & 85.1 & 36 \\
\hline Sri Lanka & 73.6 & 35 \\
\hline Indonesia & 48.4 & 27 \\
\hline Moldova & 43.8 & 26 \\
\hline Pakistan & 18 & 24 \\
\hline India & 79.8 & 19 \\
\hline Bangladesh & 41 & 18 \\
\hline Nepal & 45.4 & \\
\hline
\end{tabular}

*Financial inclusion - All adults having financial institutional accounts (\% age 15+)

Sources: Author Constructed based on the Little Data Book on Financial Inclusion 2018, World Bank report "Financial Literacy around the world", 2018.

As demonstrated by the S\&P Global Fin Lit Survey in 2017, in almost every country there exists a material gap between the male and female population. When it comes to attributes such as gender, level of education, income and age, financial literacy rates fluctuate in significant ways. Globally, a 35\% of men are financially literate as opposed to a $30 \%$ of women. As revealed in table 1, out of the Sri Lankan adult population, only a $35 \%$ are financially literate and this turns out to be a severe drawback in an individual's financial literacy and their financial wellbeing. Therefore, this is a contemporary study, on financial literacy and its determinants. The determinants of financial literacy can be analysed in both individual and environment perspectives. The individual determinants may be critical buying motive in the financial service sector. Further, degree of financial literacy can be influenced in any kind of buying behaviour when customers are selecting alternative payment systems. Especially, in the financial markets, most of the consumers are severely facing financial illiteracy problem. Hence, most of them are being away from the formal financial transactions. For the well-functioning financial market, it is 
the real requirement to enchase the level of financial literacy level among financial sector consumers. With the sound financial literacy level consumers will come up with the correct financial decisions (Lusadi, 2019). Further Wanninayake and Chovancova (2012) argued that perceived values of Sri Lankan consumers is totally different than the perceived value of consumers in the western countries. Therefore, the financial literacy can be an antecedent of consumer perceived value towards the financial services. In some circumstances, consumer impulsiveness of less literate customers will be high and it can be affected to make un planned decision of Sri lankan customers in terms of the consumer's products as well as services (Karunaratne \& Wanninayake, 2018). Hence the key objective of this study is to identify the determinants of financial literacy and examine the most significant determinants to decide the level of financial literacy in Sri Lanka in customers' perspective. Accordingly, the researcher attempts to identify various individual determinants of financial literacy based on the previous literature and select most appropriate determinants relating to the customer buying behaviour of financial service market.

The significance and the expected knowledge contribution of this study will veer into three aspects. In general, this study will draw attention to the determinants of financial literacy as an important phenomenon for researching different contexts. It will aim at providing suggestions for further researches. In the empirical perspective, this study will contribute to developing a comprehensive understanding and application of consumer financial decisions in different contexts. In the practical aspect, this study will aim to provide guidelines to marketers of the financial service industry and policy decision makers in the Sri Lankan economy to develop strategies to improve the financial literacy level of the customers of financial services by improving their degree of financial inclusion. In this article the researcher will first discuss the current meaning and scope of the financial literacy along with the critical literature review to identify the key determinants of financial literacy. Then, will continue by presenting the conceptual framework, hypotheses and methodology. Discussion of the results will be presented in section four, followed by the conclusion in the final section.

\section{LITERATURE REVIEW:}

\subsection{Financial literacy: Determinants:}

According to Monique (2011), in developed economies, being financially literate might require knowledge of tax codes, insurance requirements, and credit cards, while for the 'unbanked' in the developing world, financial literacy is more likely defined by basic concepts of safe and secure savings, budgeting and wise borrowing. Therefore, Leora (2011) argued that financial literacy is positively related to formal banking and borrowing and negatively related to the use of informal sources of borrowing. Further Lisa Xu (2012) emphasis that financial literacy is still a new and evolving field of study and meaning and scope can be developed over time. Therefore, it should be analyzed in different 
perspectives for further demarking the scope of financial literacy. In terms of consumer behavior perspectives, literacy level of the consumers can be affected on the customers' willingness to pay on the different product categories (Wanninayake \& Shantha 2013). Therefore, the researcher can argue that financial literacy has a direct relationship with the demand of the financial services.

In one perspective, financial literacy has been investigated in different levels. According to Almenberg and Widmark (2011), it can be considered in three different research traditions. Accordingly, some researchers (e.g. Johnson \& Sherraden 2007; Lusardi \& Mitchell 2007; Almenberg \& Widmark 2011) investigated impact of financial literacy on decision making and behaviors of individuals. Therefore, it can be considered as behavioral perspectives. Some researchers (Bartholomae et al., 2005; Oehler \& Werner 2008; Willis 2009) investigated on ways of developing financial literacy in the societies by developing financial education. Therefore, those researchers interested to investigate financial literacy in education perspective. On the other hand, some researchers (Lusardi \& Mitchell 2007; Jappelli 2010; Almenberg \& Widmark 2011) investigated financial literacy in different demographic categories. In this study, the researcher attempts to identify the most significant determinant to decide the degree of financial literacy. Therefore, behavioral and education perspectives of an individuals also should be taken into account. Ultimately, present research focuses on the holistic perspectives of the financial literacy.

According to OECD and INFE (2012), financial literacy of the society can be developed by making financial awareness, knowledge, skill, attitude and behavior towards sound financial decisions to achieve the financial wellbeing. Those dimensions have been considered by many researchers for their studies. However, some researchers argue that financial literacy can be determined by several dimensions such as financial education (e.g. Cohen, 2011; Sheetal 2013), financial capability to achieve financial goals (e.g. Cohen, 2010; Monique 2011), ability of making informed financial decisions (e.g. Walker, 1996; Mitchell 2011) and ability to enhance financial well-being (e.g. Porter \& Garman, 1993; Sandra 2010). Therefore, it is worth to further investigate about those perspectives to understand conceptual background of financial literacy.

\subsection{Measures of Financial literacy:}

However, there remains a lack of a consensus in the academic field about the instruments for measuring financial literacy. In recent years, many studies have been conducted in the USA, such as those by Chen and Volpe (1998, 2002), Murphy \& Yetmar (2010) and Neidermeyer and Neidermeyer (2010). Studies with families from the United Kingdom have also been conducted by Lusardi and Tufano (2009) and Disney and Gathergood (2011). In addition, similar studies were conducted with university students from Japan by Sekita (2011) and from Ghana by Ansong (2011) and with retired people in Holland by Rooij et al., (2011). Analysis this situation among emerging countries and developing countries is 
important for the present study. In the Brazilian scenario, this subject has been the focus of studies conducted by Mendes-Da-Silva et al., (2012) and Norvilitis \& Mendes-Da-Silva (2013) in student sample. Independent of the measure used, many studies have proved the associations and influences of socioeconomic and demographic variables in the levels of individuals' financial literacy (Lusardi \& Tufano, 2009; Hastings \& Mitchell, 2011; Lusardi \& Mitchell, 2011; Atkinson \& Messy, 2012; Brown \& Graf, 2013; Mottola, 2013; OECD, 2013).

Most of the previous researchers identified that measurement of financial literacy should be differentiating to match with respective socio economics context (Saha, 2016; Singh et al., 2017; Roy and Jane, 2018; Lusardi et al., 2019). In this sense, the studies in the Brazilian's context are important because this country has had a set of very unique characteristics that promise the country a bright economic and social future, such as large and expanding domestic market; single language; sophisticated financial market; abundance of water, land, and sunlight etc. (Gouvea, 2012). Further previous researchers have measured the degree of financial literacy in most of the developing countries such as India (e.g. Setty, 2012; Bhushan \& Medury 2013), Bangaladesh (Ferdous \& Polonsky, 2013; Khandker, \& Cartwright, 2006), Zimbabwe (e.g. Bonga \& Mlambo, 2016) Pakistan (e.g. Zulfiqar; 2016). Comparatively researchers have paid less attention for the Sri Lankan context to determinants for the level of financial literacy. However, Heenkenda (2014) has done comprehensive study to determine the degree of financial literacy in general context. As measurements adopted by previous researchers provide direction to select most appropriate dimensions to the present research context, some of the studies have been summarized into table 2 .

Table 2: Meta-Analysis of Financial Literacy

\begin{tabular}{|l|l|l|l|l|}
\hline \multicolumn{1}{|c|}{ Author(s) / Date } & \multicolumn{1}{|c|}{$\begin{array}{c}\text { Geography } \\
\text { area }\end{array}$} & $\begin{array}{c}\text { Segment/ } \\
\text { Sample }\end{array}$ & \multicolumn{1}{|c|}{ Determinants } & \multicolumn{1}{|c|}{ Statistical tool } \\
\hline Chen \& Volpe (2002) & $\begin{array}{l}\text { Ohio, } \\
\text { U S A }\end{array}$ & Student/ 924 & Financial knowledge & $\begin{array}{l}\text { Chronbech' s } \\
\text { alpha, ANOVA, } \\
\text { Chie square test }\end{array}$ \\
\hline $\begin{array}{l}\text { Lusardi \& Mitchell } \\
\text { (2007) }\end{array}$ & U S A & $\begin{array}{l}\text { Workers above } \\
\text { age of 50 years }\end{array}$ & $\begin{array}{l}\text { Financial knowledge } \\
\text { and behavior }\end{array}$ & Bar diagrams \\
\hline Ibrahim (2009) & Kedah, Malaysia & $\begin{array}{l}\text { Students (Age } \\
18-20 \text { years)/ } \\
200\end{array}$ & $\begin{array}{l}\text { Financial knowledge } \\
\text { and attitude }\end{array}$ & $\begin{array}{l}\text { Chronbech' s } \\
\text { Alpha, } \\
\text { correlation. Chie } \\
\text { square test }\end{array}$ \\
\hline Lusardi et al., (2010) & U S A & $\begin{array}{l}\text { Young people/ } \\
7414\end{array}$ & Financial knowledge & $\begin{array}{l}\text { ANOVA, } \\
\text { Correlation, Chie } \\
\text { square test }\end{array}$ \\
\hline Taliaferr, et al.,(2011) & U S A & $\begin{array}{l}\text { Students (class } \\
\text { X )/ NJC survey } \\
1997\end{array}$ & $\begin{array}{l}\text { Financial knowledge } \\
\text { and behavior }\end{array}$ & $\begin{array}{l}\text { Correlation, } \\
\text { Regression and t- } \\
\text { test }\end{array}$ \\
\hline Taylor (2011) & U S A & $\begin{array}{l}\text { B H survey } \\
\text { data (1991- } \\
2006)\end{array}$ & $\begin{array}{l}\text { Financial ability and } \\
\text { capacity }\end{array}$ & $\begin{array}{l}\text { Correlation } \\
\text { coefficient, } \\
\text { Regression and }\end{array}$ \\
\hline
\end{tabular}




\begin{tabular}{|c|c|c|c|c|}
\hline & & & & ANOVA \\
\hline Setty (2012) & Mumbai India & $\begin{array}{l}\text { Students (Age } \\
18-23 \text { years), } \\
100\end{array}$ & $\begin{array}{l}\text { Financial knowledge } \\
\text { and behavior }\end{array}$ & $\begin{array}{l}\text { Correlation and } \\
\text { ANOVA }\end{array}$ \\
\hline Bahmar et al., (2012) & Yazd Iran & $\begin{array}{l}\text { School teacher/ } \\
\text { Yazd county } \\
\text { school }\end{array}$ & $\begin{array}{l}\text { Financial knowledge } \\
\text { and Wellbeing }\end{array}$ & $\begin{array}{l}\text { Kolmograp h } \\
\text { Smirnoff, } \\
\text { Correlation, } \\
\text { Mean, Variance }\end{array}$ \\
\hline Shaari (2013) & Malaysia & $\begin{array}{l}\text { University } \\
\text { students/38 } 4\end{array}$ & $\begin{array}{l}\text { Financial knowledge } \\
\text { and Financial } \\
\text { Awareness }\end{array}$ & $\begin{array}{l}\text { ANOVA, } \\
\text { Multiple } \\
\text { regression }\end{array}$ \\
\hline $\begin{array}{l}\text { Bhushan \& Medury } \\
\text { (2013) }\end{array}$ & $\begin{array}{l}\text { Himachal } \\
\text { Pradesh India }\end{array}$ & $\begin{array}{l}\text { Salaried } \\
\text { individuals/ } 516\end{array}$ & Financial knowledge & ANOVA \\
\hline $\begin{array}{l}\text { Agarwalla,et al., } \\
\text { (2013) }\end{array}$ & $\begin{array}{l}\text { Ahmadab ad } \\
\text { India }\end{array}$ & $\begin{array}{l}\text { Working young } \\
\text { people/754 }\end{array}$ & $\begin{array}{l}\text { Financial knowledge, } \\
\text { behavior }\end{array}$ & $\begin{array}{l}\text { Logistic } \\
\text { regression, } \\
\text { ANOVA }\end{array}$ \\
\hline Taft (2013) & Iran & Professor/ 103 & $\begin{array}{l}\text { Financial wellbeing and } \\
\text { financial knowledge } \\
\text { concern }\end{array}$ & $\begin{array}{l}\text { t-test, Pearson's } \\
\text { Correlation, } \\
\text { Chronbech's } \\
\text { Alpha }\end{array}$ \\
\hline Bhabha, et. al., (2014) & Pakistan & working people & $\begin{array}{l}\text { Financial wellbeing and } \\
\text { financial decision } \\
\text { making concerned }\end{array}$ & $\begin{array}{l}\text { Qualitative } \\
\text { analysis based on } \\
\text { software ATLAS }\end{array}$ \\
\hline $\begin{array}{l}\text { Aggarwal, et. al., } \\
(2014)\end{array}$ & Punjab India & Framers/ 300 & Financial knowledge & Chie square test \\
\hline Heenkkenda, (2014) & Sri Lanka & 1100 households & $\begin{array}{l}\text { Financial education, } \\
\text { Financial knowledge } \\
\text { and financial attitudes } \\
\text { concerned }\end{array}$ & $\begin{array}{l}\text { Tobit regression } \\
\text { analysis and } \\
\text { cluster analysis }\end{array}$ \\
\hline Thapa (2015) & $\begin{array}{l}\text { Kathman du } \\
\text { Nepal }\end{array}$ & $\begin{array}{l}\text { University } \\
\text { students/ } 436\end{array}$ & $\begin{array}{l}\text { financial education, } \\
\text { financial knowledge } \\
\text { and Financial } \\
\text { Awareness }\end{array}$ & $\begin{array}{l}\text { ANOVA, } \\
\text { Regression } \\
\text { analysis }\end{array}$ \\
\hline Potrich, et. al.,(2015) & southern Brazil & 991 individuals & $\begin{array}{l}\text { financial knowledge, } \\
\text { financial attitude and } \\
\text { financial behavior }\end{array}$ & $\begin{array}{l}\text { Structural } \\
\text { Equations } \\
\text { Modeling (SEM) }\end{array}$ \\
\hline Zulfiqar (2016) & Pakistan & $\begin{array}{l}300 \text { working } \\
\text { women of non- } \\
\text { financial sector }\end{array}$ & $\begin{array}{l}\text { Financial wellbeing and } \\
\text { financial knowledge } \\
\text { concern }\end{array}$ & $\begin{array}{l}\text { Descriptive } \\
\text { Statistics }\end{array}$ \\
\hline Das (2016) & Assam, India & Secondary data & $\begin{array}{l}\text { Financial knowledge, } \\
\text { Financial Awareness }\end{array}$ & $\begin{array}{l}\text { descriptive and } \\
\text { exploratory }\end{array}$ \\
\hline $\begin{array}{l}\text { Bonga \& Mlambo } \\
\text { (2016) }\end{array}$ & Zimbabwe & $\begin{array}{l}\text { Relative } \\
\text { Importance } \\
\text { Index (RII), }\end{array}$ & $\begin{array}{l}\text { Financial Knowledge } \\
\text { and skills }\end{array}$ & $\begin{array}{l}\text { Box and Whisker } \\
\text { plot technique }\end{array}$ \\
\hline Arora (2016) & India & $\begin{array}{l}700 \text { private } \\
\text { sector workers }\end{array}$ & $\begin{array}{l}\text { financial knowledge, } \\
\text { financial behavior and } \\
\text { financial attitude }\end{array}$ & $\begin{array}{l}\text { Descriptive } \\
\text { research }\end{array}$ \\
\hline Karunatilaka (2016) & Sri Lanka & $\begin{array}{l}250 \text { individuals } \\
\text { in rural area of } \\
\text { Kurunegala } \\
\text { District }\end{array}$ & $\begin{array}{l}\text { Financial awareness } \\
\text { and skills }\end{array}$ & $\begin{array}{l}\text { Regression } \\
\text { analysis }\end{array}$ \\
\hline Singh \&Kumar & India & 300 respondents & Financial Knowledge & descriptive and \\
\hline
\end{tabular}




\begin{tabular}{|l|l|l|l|l|}
\hline (2017) & & & $\begin{array}{l}\text { and skills and financial } \\
\text { decision making }\end{array}$ & exploratory \\
\hline Bhargava (2017) & India & $\begin{array}{l}\text { 650 individual } \\
\text { investors }\end{array}$ & $\begin{array}{l}\text { Financial Decision } \\
\text { Making }\end{array}$ & $\begin{array}{l}\text { Regression } \\
\text { analysis }\end{array}$ \\
\hline $\begin{array}{l}\text { Loh, Peong, \& Peong } \\
(2019)\end{array}$ & Malaysia & $\begin{array}{l}150 \text { young } \\
\text { working adults }\end{array}$ & $\begin{array}{l}\text { Financial behavior and } \\
\text { knowledge }\end{array}$ & $\begin{array}{l}\text { Multiple } \\
\text { regression } \\
\text { analysis }\end{array}$ \\
\hline Rai et al., (2019) & India & $\begin{array}{l}394 \text { working in } \\
\text { financial sector }\end{array}$ & $\begin{array}{l}\text { examine financial } \\
\text { literacy are financial } \\
\text { knowledge, financial } \\
\text { behavior and financial } \\
\text { attitude }\end{array}$ & $\begin{array}{l}\text { Structural } \\
\text { equation model } \\
\text { approach }\end{array}$ \\
\hline
\end{tabular}

Source: Kumari, $2020^{a}$

According to the given summery of the literature, most of the previous researchers, irrespective to the nature of the country, have adopted to the financial knowledge to determine the level of financial literacy in the respective countries. Further financial education and financial well-being also considered as important dimensions. However, Thapa (2015) argue that financial education is an input for developing financial literacy and Ranjana (2014) argued that financial decision making and financial well-being become consequences of financial literacy. Further several researchers (e.g. Caroline et.al., 2015) emphasis that financial literacy of rural communities should be determined in knowledge as well as behavioral perspectives. Moreover, Heenkenda (2014) noted that financial knowledge can be convert into behavior based on financial skills and financial attitudes. Based on the empirical research among Indian women, Arora (2016) found that three parameters i.e. financial knowledge, financial behavior and financial attitude were used to assess the level of financial literacy and found that the general awareness about financial planning tools and techniques among women remains poor. The study concluded that women are better in terms of financial attitude and behavior as compared to financial knowledge.

Therefore, the researcher reasonably assumed that five dimensions such as financial awareness, financial knowledge, financial skills, financial attitudes and financial behavior can be considered as most suitable dimensions of financial literacy in the present research context.

\subsubsection{Financial Awareness:}

According to the Global Financial Development Report (GFDR) in 2018, the financial literacy rate of world population was only $33 \%$, in a women's point of view it was $30 \%$. Therefore, this low level of financial literacy in the modern economy consider as a global issue which is the main barrier for financial decision (Wolla, 2017; Adam, Boadu \& Frimpong, 2018: Kumari, 2016: Kumari,2018). while considering $35 \%$ of financial literacy rate for male it is much higher than female. Financial illiteracy affects not only the decision-making power, but economy as a whole for achieving inclusive growth 
(Albeerdy \& Gharleghi, 2015; Zahirovic-herbert et al., 2016; Roy et al.,2018). Financial inclusion is the outcome of financial literacy and positive financial awareness whereas level of financial wellbeing determines the economic empowerment of people. Economic empowerment is vital to recognize as the right and to accomplish the greater developmental goals such as, poverty reduction, education, financial wellbeing and economic growth. Financial awareness introduced as an important determinant of financial inclusion and are positively correlated to each other (Lusardiet al., 2019). Financial inclusion and economic empowerment is highly dependent on the financial literacy (Kumari, 2020 ${ }^{\mathrm{b}}$ ).

Financial awareness is an important dimension (Grohmann \& Menkhoff, 2015) in understanding the link between financial literacy and level of financial inclusion of people's financial decisions (Bannier \& Schwarz, 2018). It is also considered an essential tool to support economic growth in the twenty-first century (Potrich \& Vieira, 2018). In the modern world, global financial markets are inherently more complex. A variety of complex financial instruments and services are offered by financial institutes in financial markets, even to lower income group (Wolla, 2017; Garg \& Singh, 2018). Financial awareness is important that people to know and understand the modern financial transactions (Potrich \& Vieira, 2018). For example, people may open the account without a minimum deposit (Garg \& Singh, 2018). In other words, mismanagement of money will occur where there is a lack of financial awareness (Nanda \& Samanta, 2018). This is in line with Garg and Singh (2018) who state that organizations and economies are aim to increase individual financial literacy, especially rural poor (Rai et al., 2019). This indirectly supports to enhance the empowerment of individuals and economic growth in the country (Potrich \& Vieira, 2018). Prior research has shown that improving financial literacy may enhance the people's financial empowerment and reduce the levels of poverty. On the other way, access to financial resources help in gaining wide range of self-empowerment and develop their decision-making power results the reduction in poverty, increase financial wellbeing and economic growth. Therefore, financial literacy positively contributes in wellbeing of people, strengths the economy and promotes economic growth (Roy \& Jain, 2018). Therefore, this research intends to investigate the financial awareness as a dimension of financial literacy.

\subsubsection{Financial Knowledge:}

Financial knowledge is often considered central root of financial literacy (Stanovich, 2000) and it consists of individual's knowledge of the financial system and understanding of alternative options in using financial resources (Rangsubhe, 2013). Therefore, Annamarie (2011) noted that financial knowledge may have direct impact of planning the financial resources and implementing those plans by changing the behavior. Therefore, Annamaria (2014), further argued that developing financial literacy among communities can be considered as investment in human capital development. Financial knowledge was proposed by Joo (2008) as an element of personal financial wellness including financial satisfaction, financial behavior, financial attitudes, and status of achieving financial objectives. 
Therefore, financial knowledge is an integral dimension of financial literacy but not a same concept (Sandra 2010). However, some of the conceptual definitions of financial literacy has been only focused on financial knowledge (e.g. Hogarth \& Hogarth, 2002). Further Heenkenda (2014) explored that financial literacy has an additional application dimension which implies that an individual must have the ability and confidence to use his/her financial knowledge to make financial decisions. Therefore, in developing an instrument to measure financial literacy, it would be important to determine not only if a person knows the information but also if he/she can apply it appropriately (Sandra, 2010).

On the other hand, Coronel and Filho (2015) argue that individuals are considered as financially literate, if they are competent and can demonstrate they have used knowledge what they have learned. Accordingly, financial literacy obtained by people through practical experience and active integration of knowledge (Arora, 2016). Further, Greenspan, (2001) emphasis that individual should develop the knowledge of using technology also important aspect for making accurate financial decision. Further Moore (2003) argued that when people become more literate, they become increasingly more financially sophisticated and it is conjectured that this may also mean that an individual may be more competent. Further some researchers have shown that the educated individuals are more likely to have own stocks and less prone to use high-cost borrowing (e.g. Campbell, 2006; Lusardi \& Scheresberg 2013). Therefore, Lusardi (2019) concluded that educated people with sound knowledge about the financial system may involve with accurate financial decisions.

In some perspectives, individual traits such as cognitive ability, personality type, and preferences may affect financial knowledge and skills acquisition, inherent motivation and confidence to make consequential financial decisions have impact on levels of financial literacy (Hung, 2012). Further Annamaria (2011) argued that demographic characteristics of highly financially literate individuals are not highly important in financial decision making. Some researchers (e.g. Courchane, 2005) in rural areas people are having money but they invest money in an informal financial sector to get short term benefits. Sometimes, people to keep the money in their houses without opening bank accounts. Further, financial literacy often entails the knowledge of properly making decisions pertaining to certain personal finance areas like real estate, insurance, investing, saving, tax planning and retirement (Saha, 2016; Singh et al., 2017; Roy and Jane, 2018; Lusardi, 2019). According to Chang, (2005), financial literacy may cover the intimate knowledge of financial concepts like compound interest, financial planning, the mechanics of a credit card, advantageous savings methods, consumer rights, time value of money etc. In this perspectives, financial literacy involves imparting knowledge about the risk and return of financial products to the users and providers of these products. Therefore, this knowledge may help in identifying the containing risks and maintaining stability in the financial system (Lusardi \& Mitchell, 2007). Accordingly, Ranjana (2014) argued that with knowledge, financial market players are expected to control their avarice for higher returns, keeping in view their inherent risk-taking abilities. 
With considering aforesaid discussions, it is clear that financial knowledge can be considered as a main determinant of financial literacy.

\subsubsection{Financial Skills:}

Financial skills mean the ability to use the knowledge of financial services implied in financial literacy (Monique, 2011). Empirical evidence suggests financial literacy has significant impact on financial status of an individual (Moore, 2003; Perry \& Morris, 2005). Further Stango \& Zinman (2009) noted that financially literate people become wealthy by accumulating wealth. However, some researchers (e.g. Mwathi, Kubasu \& Akuno, 2017) argued that all persons with sound financial knowledge make accurate financial decisions. Chen and Volpe (1998) emphasis that any individual should have a skill to evaluate the new and complex financial instruments to make informed judgments to maximize the benefits of financial decisions. Moore (2003) further argue that individuals are considered financially literate, if they are competent and can demonstrate they have used knowledge they have learned in making financial decisions. Further if anybody doesn't have ability to analyse available financial options, he cannot be considered as financially literate individual (Chen \& Volpe, 2002). Therefore, financial skills enable individuals to make informed decisions about their money and minimize their chances of being misled on financial matters. Accordingly, person should have knowledge as well as skills to make some better financial decisions in life (Sheetal, 2013). Therefore, boosting financial literacy skills may well be critically important for economic and social welfare not only of this generation, but of those to come (Annamaria, 2011; Saha, 2016; Singh et al., 2017; Roy and Jane, 2018; Lusardi, 2019).

On the other hand, Ranjana (2014) argued that the present century recognizes financial literacy as an essential life-skill that is every human being's basic right. Further current economic conditions have raised serious concerns about financial security, especially for those who lack the skills and resources to withstand financial market downswings and take advantage of upswings (Angela, 2009). Mwathi, Kubasu and Akuno (2017) further noted that when people become more experienced in financial matters, they increasingly become financially sophisticated and it is predicted that individual become more financially competent. Lusardi and Mitchell (2006) emphasis that financial literacy requirements change over the life time of an individual in response to the changing financial needs and are therefore important in the personal decision making due to the unique nature of the financial products supplied; which could be complex, long-term and have wide social coverage. However, in the present context, many people have financial knowledge but do not have the basic financial skills necessary to develop and maintain a budget, to understand credit, to understand investment vehicles, or to take advantage from the banking system (Annamaria, 2011). 
On the other hand, financial education can be used as a tool for developing financial skills. According to above discussion, it was further justified that financial skills is a key dimension of the financial literacy. The importance of financial education has improved in recent years due to the developments in financial markets as well as demographic, economic and policy changes. More and more financial markets are becoming more sophisticated and new products are continuously offered (Dean, 2012). The scope of financial education is much bigger and broader and includes financial literacy, financial expectations, and satisfaction (Rai et al., 2019). According to (Arrington, 2009) by broadening people's understanding of financial options and principles, financial education builds skills to use financial products and services, and promotes attitudes and behaviors that support more effective use of scarce financial resources. When linked to the financial inclusion agenda the implicit argument is that financial education will motivate the learner to adopt available formal financial services (Cohen, 2011). Therefore, many countries have taken national initiatives to increase the financial education through formal education system to develop the financial skills of future generations (Sheetal, 2013; Saha, 2016; Singh et al., 2017; Roy and Jane, 2018; Lusardi, 2019).

\subsubsection{Financial Attitude:}

Financial attitudes refer to one's beliefs and values related to various personal finance concepts, such as whether one believes it is important to save money (Robb, 2011). Ranjana (2014) argue that the way of people thinks and feel about money issues may have significant impact upon how receptive they are to learning about money. Attitudes towards money and the financial system has significant impact on healthy financial behavior (Tang, 1995). Further many studies reported that financial attitudes are directly associated with financial satisfaction of the people (Hayhoe \& Wilhelm, 1998; Lim, Teo, \& Loo, 2003; Paul, 2008) emphasis that overcoming and managing negative financial attitudes is an important part of improving people's ability and willingness to engage with their money in an informed way. Financial socialization is one of the main determinants of the financial skills of the people.

Financial socialization refers to different ways that one may develop financial knowledge and attitudes. According to Gina (2012), financial attitudes effects on individuals' behavioral traits, such as their capacities for self-control, planning, and patience, affect their ability to stay out of financial trouble. Traits emerge as having a stronger impact on the incidence of financial distress than education or financial literacy (McCarthy, 2010). Behavioral traits emerge as having a stronger impact on the incidence of financial distress than education or financial literacy (Roberts \& Jones 2001). For example, while having either a college education or being financially literate reduces the likelihood of getting into financial trouble; being impulsive can undo all of this benefit (McCarthy, 2010). Attitudes and preferences are considered to be an important element of financial literacy (Danes \& Hira, 1990). If people have a rather negative attitude towards saving for their future, for example, it is argued that they will be less inclined to undertake such behavior. Similarly, if they prefer to priorities short-term wants 
then they are unlikely to provide themselves with emergency savings or to make longer term financial plans.

Further Xiao et al. (1995) discussed about affective, cognitive, and behavioral aspects of attitudes and those aspects can be applied for the financial attitudes as well. Further Warwick and Mansfield, (2000) noted that young educated people in the developed countries may have realistic attitudes toward credit cards and the repayment of money. Recently, many researchers (e.g. Grabner, Krauter \& Kaluscha, 2003; Kim et al., 2005; Saha, 2016; Singh et al., 2017; Kumari,2017: Roy and Jane, 2018; Lusardi, 2019) have investigated about financial attitudes and tendency for using on line payments and e cash in different socio-economic contexts. Many of them revealed that most of the customers in developing countries have negative attitude towards using online system for their financial transactions. Therefore, in present research context, attitudes of person towards the banking habits can be key factors of their financial decisions. Further attitude of individual's towards using formal financial system will be main dimension of the financial literacy in the present research context.

\subsubsection{Financial Behavior:}

Financial behavior can be considered as another aspect of financial literacy (Lusardi \& Mitchell, 2007). Even though an individual has financial knowledge, skills and positive attitudes towards financial system, behavior will be the last determinant for better financial decisions (Taliaferro et al., 2011). According to Agarwalla et al., (2013) financial behavior means financially responsible behavior of people towards informed financial decisions. The recent worldwide economic downturn and finance company collapses have further highlighted the importance and the need for financial literacy that can lead to financially responsible behavior Ranjana (2014). Therefore, it is ensured that the financial behaviors of people are the essential factor to determine the degree of financial literacy. Kempson and her colleagues developed a model of financial capability emphasizing behaviour, while recognizing knowledge and attitudinal components. They described five domains that reflect the financial behavior of people in managing their personal finance, making ends meet, keeping track, choosing products, planning ahead, staying informed and getting help (Robson, 2012).

According to Potrich, et. al., (2015), the financial behavior of rural communities is mainly determined by their sources of income, the way they spend their money and the influencing factors of their expenditures, which shape their financial decisions and the context and the possibilities for changing behaviors which contribute to financial stress. Financial literacy is also directly correlated with positive financial behavior such as timely payment of bills and loan installments, saving before spending and using credit card judiciously (Bhushan et al., 2013). Previous researchers suggested that the level of available resources has an impact on financial behavior, as consumers with less available resources fail to meet all of their financial obligations, or lack the means to save (Aizcorbe, Kennickell \& Moore, 
2003; Hilgert et al., 2003; Saha, 2016; Singh et al., 2017; Roy and Jane, 2018; Lusardi, 2019; Rai etal., 2019).

According to McCarthy (2010), financial behavior is direct antecedent of financial decision making. The nature of financial decision-making has changed a lot in recent years, as individuals are faced with a wider range of products, many of which are more complex than products available in the past. (McCarthy, 2010). According to Leora (2011) financial literacy is found to be a key determinant of how well people make financial decisions, as well as how well they execute their financial transactions; and such information can inform saving, investing, borrowing from and planning for retirement. Further, Annamaria (2011) emphasis that everyone faces challenges when it comes to understanding their financial options. Klatt (2009) argue that financial behavior is an important matter in financial decision making among more financial options available in present market place. According to Mitchell (2011) self-control and time preference in financial decision-making is generally thought to capture an individual's choice of whether to spend their money now, or delay gratification for later, for example by saving. Further Walker (1996) explored that self-control is thought to be an important influence on a person's financial decisions. Several studies have found that a preference for the future and selfcontrol have a positive impact on saving and financial 'coping' (Groenland \& Nyhus, 1994; Lea et al., 1995: Xiao \& Porto, 2017). Therefore, financial behavior considered as an important dimension in determining financial literacy in present research context.

According the critical literature review presented in above section, most of researchers commonly endorsed five determinants in different socio-cultural context. Those are financial awareness (Grohmann \& Menkhoff, 2015; Bannier \& Schwarz, 2018; Potrich \& Vieira, 2018), Financial Knowledge (Joo, 2008; Sandra 2010; Hogarth \& Hogarth, 2002; Heenkenda 2014), Financial Skills (Chen and Volpe 1998; Moore, 2003; Chen \& Volpe, 2002; Sheetal, 2013), Financial Attitude (Grabner, Krauter \& Kaluscha, 2003; Kim et al., 2005; Saha, 2016; Singh et al., 2017; Roy and Jane, 2018; Lusardi, 2019), Financial Behaviour (Aizcorbe, Kennickell \& Moore, 2003; Hilgert et al., 2003; Saha, 2016; Singh et al., 2017; Roy and Jane, 2018; Lusardi, 2019; Rai etal., 2019). Based on the arguments of those researchers aforesaid five dimensions can be considered as most appropriate individual determinants to financial literacy in the present research context. Accordingly, the researcher developed the conceptual framework which is depicted in figure 1. 


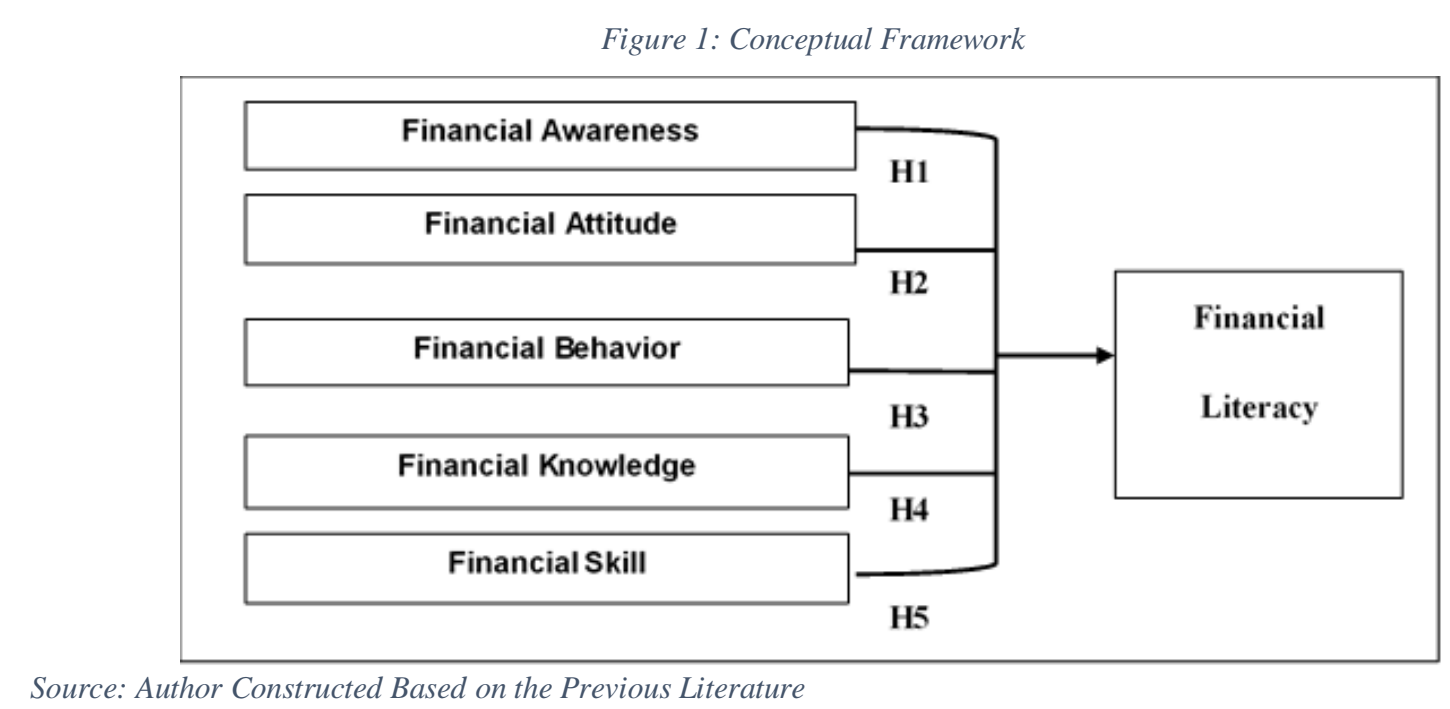

Based on the above literature and other empirical evidences relating to the field of study, five hypotheses were developed to be empirically tested in the present research context.

- H1: There is a significance influence of financial awareness on financial literacy

- H2: There is a significance influence of financial attitude on financial literacy

- H3: There is a significance influence of financial behavior on financial literacy

- H4: There is a significance influence of financial knowledge on financial literacy

- H5: There is a significance influence of financial skills on financial literacy

\section{RESEARCH DESIGN:}

Present study was designed based on deductive approach in positivist research paradigm, conceptual framework and hypotheses were developed based on the empirical literature. There were five main hypotheses formulated and tested. As survey method was adopted to primary data collection, researcher administrated questionnaire was employed as the research instrument (Sekaran \& Bougie, 2016). The target population was taken from an individual representing nine provinces in Sri Lanka. Further, sample size 500 based on the Cochran's sample size estimating formula. The multilevel mixed sampling method was employed. Further, the researcher conducted meta-analysis to find out the determinants which are mostly used by the previous researchers. Measurement items are accurately represented in respective determinants of financial literacy. Confirmatory tetrad analysis (CTA) was conducted to confirmed the reflective nature of the financial literacy (Hair, Gudergan, Ringle, \& Sarstedt, 2018). The researchers employed the Smart-PLS 3 as the main analytical software. 


\section{FINDINGS:}

According to the output results mentioned in table 3, all $p$ (probability) values are below 0.05 and all the $t$ value are above 1.96. Therefore, all four hypotheses are empirically supported. The results further verified that there is no zero laid between lower confident interval and upper confidence interval. the most significant determinant of financial literacy is financial knowledge with the highest $t$ value (60.140) among the other determinants. The financial skills $(t=58.648)$ were recognized as the second most influential determinant to determine the degree of financial literacy in Sri Lanka. Financial awareness was identified as the least significant determinant due to the respective path coefficient has the lowest $t$ value (15.443). But when it considers the overall picture about the determinants which were employed as to defined the financial literacy, it was denoted that all are getting high $t$ values as well as archived high $p$ values. It shows that all the determinants are significantly affected to determine the financial literacy level in the research context. In order to test the hypotheses, the researcher formulated five hypotheses and all the hypotheses were empirically supported.

\section{Figure 02: Relationship Between Financial Inclusion and the Dimensions}

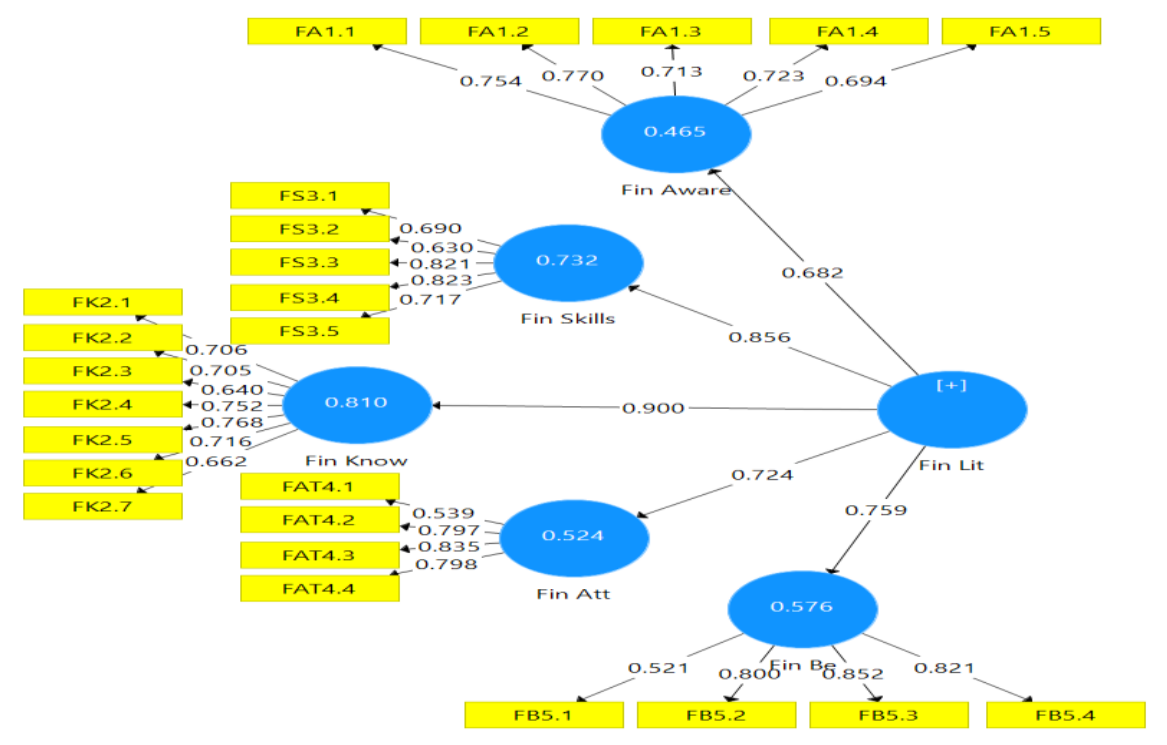

Table 03: Dimensions of Financial Literacy

\begin{tabular}{|c|c|c|c|c|c|c|c|c|}
\hline & $\begin{array}{l}\text { Stan. } \\
\text { Beta }\end{array}$ & $\begin{array}{l}\text { Sample Mean } \\
\text { (M) }\end{array}$ & $\begin{array}{l}\text { Stan. } \\
\text { D }\end{array}$ & $\begin{array}{l}\mathrm{T} \\
\text { Statistics }\end{array}$ & $\begin{array}{l}\mathrm{P} \\
\text { Values }\end{array}$ & $\begin{array}{l}2.50 \\
\%\end{array}$ & $\begin{array}{l}97.50 \\
\%\end{array}$ & Hypotheses \\
\hline $\begin{array}{l}\text { Financial Literacy -> Financial } \\
\text { Awareness H1 }\end{array}$ & 0.682 & 0.682 & 0.044 & 15.443 & 0 & $\begin{array}{l}0.58 \\
6\end{array}$ & 0.758 & $\begin{array}{l}\text { H1 } \\
\text { Accepted }\end{array}$ \\
\hline $\begin{array}{l}\text { Financial Literacy -> Financial attitude } \\
\text { H2 }\end{array}$ & 0.724 & 0.724 & 0.028 & 26.181 & 0 & $\begin{array}{ll}0.66 \\
4 \\
\end{array}$ & 0.774 & $\begin{array}{l}\mathrm{H} 2 \\
\text { Accepted }\end{array}$ \\
\hline $\begin{array}{l}\text { Financial Literacy }->\text { Financial } \\
\text { behavior } \mathbf{H 3}\end{array}$ & 0.759 & 0.76 & 0.025 & 30.462 & 0 & $\begin{array}{l}0.70 \\
8\end{array}$ & 0.805 & $\begin{array}{c}\mathrm{H} 3 \\
\text { Accepted }\end{array}$ \\
\hline $\begin{array}{l}\text { Financial Literacy -> Financial } \\
\text { knowledge } \mathbf{H 4}\end{array}$ & 0.9 & 0.9 & 0.015 & 60.140 & 0 & $\begin{array}{ll}0.86 \\
7\end{array}$ & 0.925 & $\begin{array}{l}\mathrm{H} 4 \\
\text { Accepted }\end{array}$ \\
\hline $\begin{array}{l}\text { Financial Literacy -> Financial skill } \\
\text { H5 }\end{array}$ & 0.856 & 0.856 & 0.015 & 58.648 & 0 & $\begin{array}{l}0.82 \\
4\end{array}$ & 0.882 & $\begin{array}{l}\text { H5 } \\
\text { Accepted }\end{array}$ \\
\hline
\end{tabular}

Source: Author Constructed Based on the Output Results 
According to the research objectives, it is needed to examine the most significant determinants of the financial literacy among Sri Lankan consumers. As per the findings discussed in the above paragraph, all the respective path coefficients are estimated as statistically significant. Therefore, the results demonstrate that all the five hypotheses were accepted and all the objectives were achieved. Therefore, the overall findings implied that all the determinants are a statistically significant and positive impact on the degree of financial literacy in Sri Lanka. Therefore, the results confirmed that objectives supported through literature as well as through empirical evidence in the present research context.

According to the previous literature, financial literacy was measured by using different dimensions in different contexts. In the most of the countries, the researchers adopted to same dimensions employed in the present study. Even though those studies were carried out in the various socio-cultural contexts, the very few studies have been focused on this issue in the customer point of view. Accordingly, the present study was revealed that the most significant determinant of financial literacy is financial knowledge with the highest $\boldsymbol{t}$ value among the other determinants. The financial skills were recognized as the second most influential determinant to determine the degree of financial literacy in Sri Lankan financial sector consumers. Financial awareness was identified as the least significant determinant due to the respective path coefficient has the lowest $t$ value. Therefore, it can be emphasis that present research is able to fill the literature gap emphasized by the researcher based on the relationship between determinants and financial literacy.

\section{CONCLUSION}

Based on the research findings, it was revealed that financial knowledge has made the highest significant contribution to the degree of financial literacy of consumers in financial service industry in Sri Lanka. And the financial awareness level identified as the least significant determinant of financial literacy. In Sri Lankan context, most of the government and private institutes determine the degree of the financial literacy by considering the awareness level. However, it is not reliable indicators to the decision making on the financial products and services. On the other hand, if customer has awareness about the attributes and the benefits of the financial products, they may create the behavioral intension towards the buying decision with having sound knowledge on those products and services. Therefore, policy decision makers should always think about just awareness programme about the formal financial system may not have significant impact of the financial literacy level. Therefore, it is a good finding for the policymakers to pay their attention to the financial knowledge as the highest significant factor for further improvements. According the findings of this study, the financial awareness is the basic requirement for creating the potential customers for the financial service sector. Therefore, the marketers should use appropriate promotional strategies to provide real knowledge about the pros and cons of formal financial instruments to do their transactions. Subsequently, the potential customers may 
develop the financial skills, attitudes and behavior to use the formal financial instruments and make the demand for services in the formal financial services.

Accordingly, the attention of policymakers should be focused on financial awareness as the least significant factor of financial literacy to encourage as the less performed determinant for enhancing the financial literacy level in Sri Lanka. Further, this study makes a special contribution to existing literature and for the policymakers as it provides a clear understanding of significant determinant on financial literacy to enhance the overall financial wellbeing of the consumers. One of the main limitations of the study is, the research has only focused on the customer perspective in a quantitative method. It is recommended for the future researchers to focus on qualitative research method as well.

\section{REFERENCE:}

[1]. Adam, A. M., Boadu, M. O., and Frimpong, S. (2018). Does Gender Disparity in Financial Literacy Still Persist After Retirement? Evidence from Ghana. International Journal of Social Economics, 45(1), 18-28.

[2]. Adami, R., Carosi, A., and Sharma, A. (2018). Retirement Saving in the UK: A Life-Cycle Analysis. Studies in Economics and Finance, 35(1), 109-136.

[3]. Aggarwal, N. (2014). Financial Literacy among farmers: Empirical evidence from Punjab. Pacific Business Review International, 6 (7),36-42.

[4]. Arora, A. (2016). Assessment of Financial Literacy among working Indian Women, https://www.researchgate.net/publication/298790053, Article March 2016.

[5]. Arrondel L, Debbich M., \& Savignac, F. (2013) Financial literacy and financial planning in France. Numeracy 6(2), 1-17.doi: $10.5038 / 1936-4660.6 .2 .8$

[6]. Bahmar, Z. (2012). Investigating the relationship between financial literacy and prosperity and the determining association with demographic variables, Indian Journals of Fundamental and Applied Research, (pp.1143-11542)

[7]. Beck, T., Demirguc,-Kunt, A., \& Martinez-Peria, S. (2007). Reaching out: access to and use off banking services across countries, Journal of Financial Economics, 85(1),234-266.

[8]. Beck, T., Demirguc-Kunt, A., \& Levine, R. (2008). Finance, inequality, and the poor, Journal of Economic Growth, 12, 27- 49.

[9]. Beckmann, E. (2013). Financial Literacy and Household Savings in Romania. Numeracy,6(2),9.

[10]. Bhushan, P., \& Medury, Y. (2013). Financial literacy and its determinants, International Journal of Engineering, Business and Enterprise Applications (IJEBEA), 4 (2),155- 160.

[11]. Bonga, W. G., \& Mlambo, N. (2016) Financial Literacy Improvement Among Women in Developing Nations: A Case for Zimbabwe. Quest Journals, Journal of Research in Business and Management, 4(5), 22-31.

[12]. Central Bank of Sri Lanka. (2018). Annual Report. Colombo. Central Bank of Sri Lanka. 
[13]. Chen, H., \& Volpe, R. P. (2002). Gender Differences in Personal Financial Literacy Among College Students. Financial Services Review, 11(3), 289-307.

[14]. Devi, A. (2016). Financial literacy among women: A sample study in the Kamrup district of Assam. EPRA International Journal of Economic and Business Review, 4(2), 144-147.

[15]. Devlin, J. F. (2009). An analysis of influences on total financial exclusion. The Service Industries Journal, 29(8), 102-136.

[16]. Garg, N., \& Singh, S. (2018). Financial literacy Among youth. International journal of social economics. 45(1), 173-186.

[17]. Ghosh S. (2019). Financial literacy and financial inclusion unbridling the nexus. Economic and political weekly.13

[18]. Hair, J. F., Hult, G. T. M., Ringle, C. M., \& Sarstedt, M. (2017). A Primer on Partial Least Squares Structural Equation Modeling (PLS-SEM) (2ed.). Thousand Oaks, CA: Sage.

[19]. Hair, J. F., Gudergan, P., Ringle, C. M., \& Sarstedt, M. (2018). Advanced Issues in Partial Least Squares Structural Equation Modeling. Los Angeles: Sage

[20]. Hair, J. F., Sarstedt, M., Ringle, C. M., \& Gudergan, S. P. (2018). Advanced Issues in Partial Least Squares Structural Equation Modeling (PLS-SEM). Thousand Oaks, CA: Sage.

[21]. Hasler, A., \& Lusardi, A. (2017). The gender gap in financial literacy: A global perspective. Washington, DC: Global Financial Literacy Excellence Center, The George Washington University School of Business.

[22]. Haque, A. Zulfiqar, M. (2016). Women's economic empowerment through financial literacy, financial attitude and financial wellbeing. International Journal of Business and Social Science, 7, (3), 78-8.

[23]. Heenkenda, S. (2014), Inequalities in the financial inclusion in Sri Lanka: An assessment of the functional financial literacy, (Online) http://mpra.ub.uni-muenchen.de/54419/MPRA Paper No. 54419, posted 16. March 2014 11:07 UTC.

[24]. Hung, A.J. Yoong., \& E. Brown (2012). Empowering women through financial awareness and education, OECD Working Papers on Finance, Insurance and Private Pensions, No. 14, OECD Publishing.

[25]. Hussein A. Hassan Al-Tamimi, Al Anood Bin Kalli, (2009). Financial literacy and investment decisions of UAE investors. The Journal of Risk Finance. 10 (5), 500-516.

[26]. Huston, S. J. (2010). Measuring financial literacy. Journal of Consumer Affairs, 44,296-316. doi:10.1111/j.1745-6606.2010. 01170.x

[27]. Ibrahim, D. Harun, R., \& Z. Isa. (2009). A study on financial literacy of Malaysian degree students. Cross Cultural Communication, 5(4), 51-59.

[28]. Joshi M. C. (2013). India: Literacy and women's empowerment, a tracer study in ASPBAE (2012) The power of literacy: women's journeys in India, Indonesia, Philippines and Papua New Guinea, Philippines: ASPBAE

[29]. Karunaratne L.G.A.S, Wanninayake W.M.C.B. (2018), Consumer Ethnocentrism and Its Influence on 
Impulsive Buying Behaviour in Sri Lankan Milk Powder Market: The Moderation Effect by the Consumer Impulsiveness Traits, Kelaniya Journal of Management, Vol.7 (2), pp. 1-14. DOI:10.4038/kjm.v7i2.7574.

[30]. Karunathilaka, K. T. S. (2016). A Study on Financial Literacy of Rural Community in Sri Lanka: With Special Reference to Kurunegala District.17th Conference on Postgraduate Research, International Postgraduate Research Conference 2016, Faculty of Graduate Studies, University of Kelaniya, Sri Lanka.174.

[31]. Kasman, M. Heuberger, B., \& Hammond, R. A. (2018). Recommendations for improving youth financial literacy education.

[32]. Kumari D.A.T, (2016), "Financial Literacy as a Demand side Antecedent of Financial Inclusion: an Empirical Study among rural poor in Sri Lanka". Wayamba International Conference (WinC 2016).

[33]. Kumari D.A.T. (2017), "Financial Literacy: An Essential Tool for Empowerment of Women through Financial Inclusion - Literature Review". Equality and Management, Faculty of Economics and Management, University of Szczecin, Poland.

[34]. Kumari D.A.T and Aluthge C. (2018)," The determinants of financial inclusion among rural poor: An empirical study in Sri Lanka” Wayamba International Conference (WinC 2018).

[35]. Kumari D.A.T., Ferdous Azam S. M. (2019). The Mediating Effect of Financial Inclusion on Financial Literacy and Women's Economic Empowerment: A Study Among Rural Poor Women in Sri Lanka. International Journal of Scientific \& Technology Research, Vol 8, No 12, December 2019 ISSN 2277 8616. IJSTR@2019. www.ijstr.org

[36]. Kumari D.A.T., Ferdous Azam S. M. \& Siti Khalida. (2020a). Financial Literacy: As A Tool for Enhancing Financial Inclusion Among Rural Population in Sri Lanka. International Journal of Scientific \& Technology Research, Vol 9, No 4, April 2020 ISSN 2277-8616. IJSTR@2020. www.ijstr.org

[37]. Kumari D.A.T., Ferdous Azam S. M. \& Siti Khalida. (2020b). The Impact of Financial Literacy on Women's Economic Empowerment in Developing Countries: A Study Among the Rural Poor Women in Sri Lanka. Journal of Asian Social Science; Vol. 16, No. 2, ISSN 1911-2017 E-ISSN 1911-2025.Published by Canadian Center of Science and Education.

[38]. Kuznets, S. (1955). Economic growth and income inequality, The American Economic Review, 45, (1), 128.

[39]. Lee, Y., \& Kozar, K. (2005). Investigating factors affecting the anti-spyware system adoption. communications of the ACM, 48(8), 72-77.

[40]. Lehmann, E., \& Neuberger, D. (2001). Do lending relationships matter? Evidence from bank survey data in Germany, Journal of Economic Behavior and Organization, 45,339-359.

[41]. Lusardi, A. Pierre-Carl M., \& Olivia S. M. (2013). Optimal Financial Literacy and Wealth Inequality. NBER WP 18669.

[42]. Lusardi, A. Pierre-Carl M. \& Olivia S. M. (2014). Using a Life Cycle Model to Evaluate Financial Literacy Program Effectiveness. PRC Working Paper. The Wharton School, University of Pennsylvania.

[43]. Lusardi, A., \& Olivia S. M. (2014). The economic importance of financial literacy: Theory and evidence. Journal of Economic Literature. 52(1), 5-44. 
[44]. Lusardi, A. Olivia, M. S., \& Vilsa, C. (2010). Financial Literacy among the Young: Evidence and Implications for Consumer Policy. CFS Working Paper 2010/09.

[45]. Lusardi, A., \& Olivia S. Mitchell (2009). How ordinary consumers make complex economic decisions: Financial literacy and retirement readiness. NBER Working Paper 15350.

[46]. Lusardi, A., \& Olivia S. M. (2008). Planning and financial literacy: How do women fare?, American Economic Review P\&P, 98(2), 413-417.

[47]. Lusardi, A., \& Olivia S. M. (2007). Financial literacy and retirement preparedness. evidence and implications for financial education, Business Economics: 35- 4.)

[48]. Lusardi, A., \& Scheresberg, B. (2017). Financial capability and financial literacy among working women: New insights.Retrieved from http://gflec.org/wp-content/uploads/2017/03/ Research-Report_Working-Women_March-2017.pdf?x87657

[49]. Lusardi A. (2019). Financial literacy and the need for financial education: evidence and implications, Swiss Journal of Economics and Statistics,155(1), 1-8

[50]. Maarten van Rooij, Annamaria Lusardi \& Rob Alessie (2011). Financial Literacy, Retirement Planning, and Household Wealth, DNB Working Paper No 313, De Nederlandsche Bank, The Netherlands.

[51]. Mahdavi, Mahnaz. (2012). Financial literacy among educated women: Room for Improvement. Working Paper, Smith College.

[52]. OECD. (2013). Financial literacy and inclusion: Results of OECD/INFE survey across countries and by gender. Paris: OECD Centre.

[53]. Peter, J. M., \& Long, Q. T. (2019). Determinants and Impacts of Financial Literacy in Cambodia and Viet Nam. Journal of Risk and Financial Management, 12(19),1-24.

[54]. Ringle, C. M., \& Sarstedt, M. (2016). Gain More Insight from Your PLS-SEM Results: The ImportancePerformance Map Analysis. Industrial Management \& Data Systems, 116(9), 1865-1886.

[55]. Ringle, C. M., Sarstedt, M., Mitchell, R., \& Gudergan, S. P. (2018). Partial Least Squares Structural Equation Modeling in HRM Research. The International Journal of Human Resource Management, forthcoming.

[56]. Ringle, C. M., Wende, S., \& Becker, J.-M. (2015). SmartPLS 3. Bönningstedt: SmartPLS. Retrieved from http://www.smartpls.com

[57]. Roy, B., \& Jain, R. (2018). A study on level of financial literacy among Indian women. IOSR Journal of Business and Management, 20(5), 19-24.

[58]. Saha, B. (2016). A study of financial literacy of working women of Raipur city International Journal of Recent Trends in Engineering \& Research (IJRTER), 2, (11), 154-160. [ISSN: 2455-1457]

[59]. Sarstedt, M., Ringle, C. M., \& Hair, J. F. (2017). Partial Least Squares Structural Equation Modeling Handbook of Market Research,1-40, Springer.

[60]. Sekaran, U., \& Bougie, R. (2016). Research methods for business: a skill-building approach (7th ed.). 
Haddington: John Wiley \& Sons.

[61]. Setty, V. S. (2012), A study of financial literacy amongst the college students in Mumbai, Tactful Management Research Journal, ISSN: 2319-7943,06-11.

[62]. Singh, C., \& Kumar, R. (2017). Financial literacy among women: Indian Scenario. Universal Journal of Accounting and Finance, 5(2), 46-53.

[63]. Taliaferro, D. L. (2011). A review of Howard University's financial literacy curriculum, American Journal of Business education, 4(10).

[64]. Taylor, S., \& Wagland, S. (2011). Financial literacy: A review of government policy and initiatives, Australasian Accounting Business and Finance Journal, 5(2), 101-125.

[65]. Upendra Singh. (2014). Financial literacy and financial stability are two aspects of efficient economy, Journal of Finance, Accounting and Management, 5(2), 59-76.

[66]. Mathivathani V., \& Dr.M. Velumani (2014). Financial literacy among rural women in Tamilnadu, Indian Journal of Applied Research, 4 (12) ISSN - 2249-555X

[67]. Wanninayake W.M.C.B, and M. Chovancova (2012). Store Personality and Behavioral Intentions of Customers: A Comparative Study of Retail Industry in the Czech Republic and Sri Lanka. ACTA Universitatis Agriculturae Et Silviculturae Mendelianae Brunensis, Czech Republic. Vol. LX (7), pp 477 484.

[68]. Wanninayake W.M.C.B, and Shantha A. Aruna.(2013). Pricing Economic Value of Organic Rice Under Dichotomous Choice Framework: An Environmental Perspective, Kelaniya Journal of Management, Vol.2 (2), pp. 1-22

[69]. Xiao J. J., \& Porto N. (2017). Financial education and financial satisfaction: Financial literacy, behavior, and capability as mediators. International Journal of Bank Marketing, 35 (5), 805-

817. https://doi.org/10.1108/IJBM-01-2016-0009 